\title{
Muslim personality: Study of the Concept of Personality Structure and Psychological Struggles
}

\author{
Haseeb Mabrur \\ Aga Khan University, Pakistan
}

\begin{abstract}
This article discusses Muslim personality from the aspects of Personality Structure and Psychological Struggles. In Islam the Muslim personality is synonymous with Islamic morals, it is a harmonious blend of the system of the heart, reason, and lust that causes behavior and is a characteristic of Muslims. Because of that, the characteristic of a Muslim personality is that he always keeps his heart to obey Allah so that he always gets his light and keeps away from all his prohibitions which are human excrement. The structure of the Muslim personality includes three substances, namely body or body, spirit or spirituality, and nafsani or soul, the soul itself consists of the heart, reason, and lust. While lust consists of lust, anger, and muthmainah. All of these are the structures of Islamic personality, which if the system works well all will form the personality of a Kamil or a complete human being who is calm, always does good, tawakkal, and avoids despicable traits.
\end{abstract}

Keywords: Muslim personality, Personality Structure, Psychological Struggle

Received : August 17, 2020

Received in Revised: August 25, 2020

Accepted: August 28, 2020

\section{Introduction}

According to the language of the essence, it means truth or something that is true or the origin of everything. It can also be said that essence is the essence of everything or the soul of things (Allison \& Zelikow, 1971; Lorenz, 1995; Darlington, 2000). Meanwhile, humans are the most perfect creatures that God has ever created. Perfection possessed by humans is a consequence of their functions and duties as caliphs in the face of this world.

Talking about humans in the view of science is very dependent on the methodology used and the underlying philosophy. Psychoanalytic theorists call humans homo volens (creatures of desire) (Carr \& Pihlanto, 1998; El-Shamy, 1976; Funk \& Shaw, 1982). According to this school, humans are creatures that have interaction behavior between biological (id), psychological (ego), and social (superego) components. In humans there are elements of animal (animal), rational (intellect), and moral (value). Behaviorists call humans homo mehanibcus (machine humans). Behavior was born as a reaction to introspection (a school that analyzes the human psyche based on subjective reports and psychoanalysis (a flow that talks about the invisible subconscious). Behavior analyzes visible behavior. According to this flow, all human behavior is formed as a result of the learning process to their environment, it is not due to aspects. Cognitive theorists call humans homo sapiens (thinking humans). According to this school, humans are no longer viewed as beings who react passively to their environment, creatures that always think. Cognitive theorists criticize the opinion that tends to considers that thoughts are not real because they do not appear to affect events, even though thinking, deciding, expressing, understanding, etc. are facts of human life. 


\section{Definition of Personality}

Personality in Arabic is called as-shakhshiyyah, derived from the word syakhshun, meaning, person, or person or person. Personality can also be defined as a person's identity (haqiiqatus syakhsh). A person's personality or syakhshiyyah is formed by his way of thinking (aqliyah) and his way of acting to fulfill his needs or desires (nafsiyah).

Personality comes from the word Personality (Latin) which means mask or mask. Namely, the face cover is often used by stage performers, which means to describe a person's behavior, character, or personality. This is done because there are distinctive characteristics that only a person has, either in the sense of a good or bad personality. Philosophically it can be said that the person is "the real me" and the personality is the "appearance of the I" in a certain form of behavior.

Here comes the general idea that personality is the impression a person gives to others that are obtained from what is thought, felt, done which is revealed through behavior. Furthermore, based on the meaning of these words the experts put forward the definition as follows: Woodworth: The quality of all one's behavior. Morrison: The totality of what an individual achieves by presenting the cultural results of social evolution. Hartmann: The integrated arrangement of the general characteristics of an individual as expressed in the distinctive features he pays attention to others. William James: personality is a multi-layered unity element of the material self, social self, spiritual self, and pure ego. Sigmond Freud: personality is composed of three systems, namely id, ego, and superego. Meanwhile, John Hocke has put forward the theory of tabula, flavors, or wax boards that are ready to be drawn, in contrast to Islam which places fitrah as a basic psychological potential. Muslim intellectuals define personality as a form of integration between the system of the heart, intellect, and human passions that cause behavior.

\section{Muslim Psychology and Personality}

Psychologists view personality as a fixed psychological structure and process, which constitutes individual experiences and shapes individual actions and responses to the environment in which they live (Larsen, 1989; Molden \& Dweck, 2006; Fleeson, 2001).

During its growth period, personality is dynamic, changing due to environmental influences, life experiences, or education. Personality does not happen automatically but is formed through a long life process. Thus, whether a person's personality is good or bad, strong or weak, civilized, or barbaric is entirely determined by the factors that influence the person's life journey.

The substance of the nafsani has three powers, namely (1) heart or divine nature, human reason or nature, and lust or firah hayawaniah. Personality is basically a combination of the three forces, it's just that usually one of them dominates the other.

Al Kindi defines the soul as an nafs nathiqah whose substance is divine rabbani which comes from the light (nur) of the creator. Therefore, the soul or heart must always be turned on by divine light. In Islam, the living heart is the source of kindness and the death of the heart is the source of evil. The root of all the goodness and happiness of a servant is the perfection of his life and light. A healthy and living heart will be able to distinguish between good and bad. 
The personality of a Muslim means demanding that his soul always lives with divine nur. This is what distinguishes between personalities according to Islamic concepts. Islamic personality is the characteristic, character, and character of Muslims. Muslim personality or often called Islamic morals, namely the behavior of a Muslim which is a harmonious blend of heart, reason, and human nature.

The personality for a Muslim is one who always keeps his heart to always obey Allah and be happy because he is close to Allah so that he gets his rays by always doing worship and other pious deeds ... while a dirty and rejecting heart that appears from his body members is a despicable nature. heart marks that are dirty and dark without light.

In this case, Hasan al Basri said: Moral goodness is the sweetness of his face, gives advantages, and prevents pain. Meanwhile, Al Washili said that good morals are pleasing people at times of joy and sorrow. And Sahal al Tsauri said that good morals are at least enduring the suffering of others, not repaying other people's injustices, asking forgiveness from Allah for those who do wrong, and have mercy on him.

If seen from the definition of this definition, according to the author's opinion, things like this are the fruit of morals because morals themselves are a spiritual work system that is contained in the human soul.

Sometimes under certain conditions, there is a change in behavior. This is because one soul substance dominates others. If a person's interaction is dominated by lust, what appears is a liar, selfishness, hunks, delusions, and anger. In Islamic psychology, this is called a sick soul. But if what dominates the mind and heart, what will appear are praiseworthy qualities and ma'rifat to Allah, this will bring happiness.

The work of the heart or a personality that is dominated by the heart will produce mutmainah personalities, which are personalities based on faith, Islam, and ikhsan. Meanwhile, a personality dominated by reason will produce a lawwamah personality, a personality that is based on social, moral, and rational grounds. And a personality dominated by lust produces an angry personality, it is productive, creative, and consumptive.

Therefore, there are personalities that are attractive and some are despicable. An attractive personality is a personality that has positive traits such as being diligent, patient, generous, and helpful. While a despicable personality is a negative personality such as lazy, grumpy, stingy, arrogant, and so on.

\section{Islamic Personality Structure}

Islamic psychological discourse on structure and personality is very closely discussed with the human substance. According to Islamic philosophers and psychologists, the soul substance consists of three parts, namely body, spiritual, and nafsani or lust. The physical substance in the form of a human physical organism is more perfect than other physical beings which have the elements of earth, air, fire, and water. It will live if it is given the life force or al bayah.

The substance of the spirit is the substance which is the original perfection. Al Gazali called it a gentle and spiritual lathifah. The spirit was there when the body was not there and still exists even though the body is dead. Fathur Rahman stated that the spirit is a mandate, because of that it is unique compared to other creatures. With this mandate he became a caliph on earth. The substance of the nafsani means soul, life, or spirit, the connotation is the personality and 
psycho-physical substance of humans. This nafs is a combination of body and spirit. Therefore the nafs are physical and spiritual potential. It is in the form of its actualization potential to form a Muslim personality, which is a harmonious blend of heart, mind, and self.

The Islamic personality structure is a harmonious blend of heart, mind, and nafsani. Al Qalb or the heart is organic material that has a cognition system that is emotionally empowered. $\mathrm{Al}$ Gazali states that the heart has an instinct called al nur al ilahy and al bashirah al bathinah (the inner eye). The heart in the physical sense is the heart (heart) not the heart (liver). The heart in the spiritual sense is showing the conscience and spirit. This heart functions as a guide, controller, and controller of the other nafs structures. If this heart functions normally, then humans will be good according to their original nature. Because the heart has a divine nature that is emitted from God. He is not only able to know the physical environment and the environment but also to know the spiritual and religious environment. Regarding this heart, Rasulullah SAW once said: "In fact, in the body there is a lump of flesh, if it is good then all bodies become good, but if it is damaged then all bodies become corrupted anyway, remember that it is the heart ".

According to Huzaifah, the heart is divided into four, namely a clean heart, namely (1) the heart of a believer and receiving light (2) a closed heart, namely the heart of an infidel, a heart that is blind and does not see the truth (3) a heart that is turned over, namely the heart of a hypocrite namely seeing the truth but then denying it (4) a heart that has two provisions, namely the provision of faith and the provision of hypocrisy, it depends on which one is the most dominant. A person whose heart is illuminated by God will have a strong personality, steadfast, and not easily give up. And if he has muthmainah lust he will be calm and optimistic because he believes God's grace will definitely be given.

In order for the heart to always get divine light according to Imam Al Gazali, it must be knowledgeable and iradah (willing). With science, humans will know all the affairs of the world and the hereafter, and according to al Gazali, the heart functions to obtain happiness in the hereafter. Psychologically the heart has emotional power (al infialy) and cognition.

The sense in etymology means al imsak (restraining) al Ribath (bonding) al Bajr (restraining) al Naby (prohibiting) and manin (preventing). Based on this meaning, what is called a wise person is a person who is able to hold and bind his lust. If the lusts are bound then the rationality is capable of existence. With intellect, a person is able to distinguish good and bad, beneficial, and harmful. Intellect is able to acquire knowledge with reasoning power (al Nazhr) and argumentative power.

Through human reason, human beings can do good, namely delaying the desire not to rush to do it so that it becomes clear to it its suitability to be done or abandoned. According to alHasan, if the work is motivated to hope for the pleasure of Allah, then do it, but if not because of Allah, it is better to postpone it first. And if the motivation is to get the pleasure of Allah, then you have to think beforehand whether in doing something he gets help or not, otherwise, it should be postponed first. And when you have the assurance of Allah's help, do it so that he will have good luck.

Muhasabah can also be done after completing something, namely whether what is done is sincere because of Allah, according to Allah's provisions. Whether time works out of control or not, good consequences or not. With goodwill, people will be saved and can get better in behavior and personality. 
Like Plato, Al Zukhaily argues that the rational soul is located in the head so that the one who thinks is the mind, not the heart. Between intellect and heart are the same to obtain cognitive power but the way and the results are different. Intellect is capable of attaining rational knowledge but not supra-rational so that it is able to reach the truth but is unable to feel its essence.

According to Al Gazali, so that humans can always be close to each other and receive divine nurses, they must be knowledgeable and have irada (will). With knowledge, someone will know all the affairs of the world and the hereafter and everything related to reason. With willingness and reason, someone will know ways to correct and look for the causes associated with it. Al Gazali argues that people who are sick with lust always want good food.

This gives us the understanding that if the person is healthy it logically means all food as long as it is healthy and halal and toyyiban will definitely taste good (delicious). Thus the desire to always want things that are delicious and delicious can be reduced or combated by healthy conditions.

$\mathrm{Al}$ Gazali also believes that knowledge gained in the heart will have the power to see and be able to distinguish various forms. The mental view and the outward view actually have the same truth, but they are different degrees. The heart is like a driver while reason is like a vehicle. The bad heart or the driver will be more dangerous than the bad vehicle itself. However, the reason is still needed to solve life's problems.

Common sense will influence a person's actions and emotions as well as his personality. Intellect is divided into two, namely sense dharuri and sense muktasabah. Dharuri is the mind that can know easily. Muktasabah intellect is a new mind that knows how to be cultivated. Muktasabah reason is divided into two, namely muktasabah, which is the mind used to solve problems related to worldliness. Muktasabah ukhrawi intellect is the mind used to reach the hereafter.

Psychologically, people who have a clean soul and perfect mind will be able to actualize themselves in life and life, namely seeing reality carefully, precisely as it is, and more efficiently. He can accept the condition of himself and others in a professional manner, namely acknowledging all the advantages and limitations of each, thus he will be able to accept input from others naturally without coercion.

Nafsani Lust is the power of the nafsani, it has two powers, namely, al-Ghadhabiyah and alSyahwaniyah. Al-Ghadhabiyah is a potential force to avoid all dangerous things. Ghadab in psychoanalysis is called defenci (defense, defense and guarding), which is an action to protect his own ego against mistakes, anxiety, and shame for his own actions, while lust in psychology is called appetite, namely desire or desire or lust, the principle is a pleasure. If his desire is not fulfilled there will be tension, the working principle is the same as the working principle of animals, both attacking beasts and tame animals which tend to sexual desire.

Lust is a subconscious structure in the human personality, if human beings are dominated by their passions, then they will not be able to exist either in this world or in the hereafter. Therefore, if a person's personality is dominated by lust, his working principle is to pursue the pleasures of the world, but if that desire is guided by the heart of divine light, his ghadab will turn into a high degree of ability. 
If the lust is controlled by divine light, what appears is good, but if that desire is controlled by Satan then what appears are shitaniya qualities and this is called a sick heart, a sick heart can heal when it returns to divine light but will it hurts more when he is controlled by evil lust.

In psychology, people who are mentally disturbed are not easily measured or checked with medical devices, to find out usually only symptoms can be seen such as their actions, behavior, and thoughts, such as anxiety, jealousy, unreasonable sadness, loss of selfconfidence, irritability., stubborn, degenerate intelligence, like to slander, annoy others, and so on.

Mental health also affects body health. Recently in medical science, the term psychotic is found, which is a mental illness, such as high blood pressure, low blood pressure, excess, shortness of breath, and so on.

The remedy for various mental illnesses and those caused by mental health is the functioning of a harmonious working system between heart, mind, and desire. And this can only be done through continuous mental training.

The harmony of the soul allows a person to relate harmoniously to the community. For that we need The Art of Interaction, namely the art of having good relationships towards good morals, as the main basis for the happiness of the people, good morals are also a major factor in improving one's personality.

In Sufism, a clean soul and a dirty soul are included in lust. And they divide lust into 3 parts:

Lust of anger, he always tends to be immoral, both immoral and spiritual. People who are dominated by angry lust will manifest their personality as being greedy, greedy, stubborn, arrogant, and other unacceptable actions such as free sex, fighting, and so on.

Lust for lawamah, he has received divine nur and likes to worship but still often does spiritual immorality then immediately takes istighfar and tries to fix it. People with a humorous personality will always evaluate themselves (self-correction) to get better.

Lust muthmainah, a personality that originates from the human heart, which always avoids despicable qualities and grows praiseworthy qualities and is always calm. The tendency is to worship, love others, increase trust, and seek the pleasure of Allah and are theocentric. According to Ibn Kholdum, the spirit of the heart is visited by the spirit of reason. The substance of this spirit of the reason is capable of knowing anything in nature. He becomes incapable of attaining knowledge because of the veil, if the veil is lost he will be able to find knowledge. In fact, some other Sufism experts divide lust into 7 parts, namely: lust for anger, lust for lawamah, lust for malhamah, lust for muthmainah, lust for al rodhiyah, lust for mardhiyah, and for our lust.

\section{Psychological Struggles}

In the human personality, there are animal and angelic characteristics that sometimes arise in a struggle between the two aspects of the human personality. Sometimes, man is attracted by the needs and lusts of his body, and sometimes he is attracted by his spiritual needs.

Al-Qur'an indicates the psychological struggle experienced by humans, namely between the tendency to physical pleasures and the tendency to the temptations of worldly life. So, it is very natural that this human nature contains a struggle between good and bad, between virtue 
and humiliation, and so on. To overcome the struggle between the material aspect and the spiritual aspect in humans requires a good solution, namely by creating harmony between the two.

Besides that, the Al-Qur'an also suggests that humans have the potential to be positive and negative. In essence, the positive potential of humans is stronger than the negative potential. It's just that the appeal of evil is stronger than the appeal of good.

The positive and negative potentials of humans are widely revealed by the Qur'an, among which there are two verses that mention the positive potential of humans, namely Surah at-Tin [95] verse 4: "In fact, we have created humans in the best possible form", And Surah al-Isra '[17] verse 70: "And indeed we have glorified the children of Adam, we carry them on land and in the sea, we give them sustenance of the good and we exaggerate them with perfect excess over most of the beings that we have created."

Meaning: Allah made it easy for Adam's son to carry transportation on land and at sea to earn a living.

In addition, there are also many verses of the Al-Quran that criticize humans and give them a negative label. Among them are people who are very persecuted and deny favors (QS Ibrahim [14]: 34), people argue very much (QS al-Kahfi [18]: 54), and humans are complaining and miserly (QS al-Ma'arij [70 ]: 19).

Actually, these two contradictory human potentials are caused by the enmity between three kinds of lust, namely the lust of ammarah bi as-suu '(the soul which always tells badness), see Surah Yusuf [12] verse 53; lust lawwamah (soul that is very reproachful), see Surah alQiyamah [75] verses 1-2; and lust muthma'innah (peaceful soul), see Surah al-Fajr [89] verses 27-30. [33] The conceptions of the three passions are the different conditions that characterize a soul in the midst of the psychological struggle between the material and spiritual aspects.

Patterns and Characteristics of Muslim Personality

Personality is a "necessity", an inner part (interior) of ourselves that still needs to be explored and discovered in order to arrive at a belief in who we really are. In the Al-Qur'an Allah SWT has explained the human personality model that has special features compared to other personality models.

Among these are Surah al-Baqarah [2] verses 1-20. This series of verses describe three models of human personality, namely the personality of the believer, the personality of the infidels, and the personality of the hypocrite.

The following are the traits or characteristics of each personality type based on what is described in the series of verses, while according to the current theme, focus on Muslim personality traits or traits according to the Qur'an and Sunnah, which are two heirlooms of the Prophet Muhammad that every Muslim must always refer to in all aspects of life. One of the most important aspects of life is the formation and development of the Muslim personality. The Muslim person desired by the Qur'an and the Sunnah is a pious person, a person whose attitudes, words, and actions are colored by the values that come from Allah SWT. There are ten profiles or characteristics that must be attached to the Muslim person, namely:

Salimul Aqidah A clean Aqidah (salimul aqidah) is something that every Muslim must-have. With clean aqidah, a Muslim will have a strong bond with Allah Most High, and with that

Copyright (C) 2020, Interdisciplinary Journal Papier Human Review, Under the license CC 
strong bond, he will not deviate from His path and provisions. With the cleanliness and stability of aqidah, a Muslim will surrender all his actions to Allah as His word which means: "Verily, my prayers, my worship, my life, and death, are all for Allah, the Lord of the worlds' (Surah Al-An'am [6]: 162 ).

Sahihul 'Worship The right worship (shahihul worship) is one of the important commands of the Prophet, in one hadith; he said: 'pray you as you see me praying.' From this expression, it can be concluded that in carrying out every worship one must refer to the sunnah of the Prophet, which means that there must be no additional or subtraction element.

Matinul Khuluq Strong morals (matinul khuluq) or noble morals are attitudes and behaviors that must be possessed by every Muslim, both in relation to Allah and with His creatures.

Qowiyyul Jismi Physical strength (qowiyyul jismi) is one side of the Muslim person that must exist. Physical strength means that a Muslim has endurance so that he can carry out Islamic teachings optimally with a strong physique. Prayers, fasting, zakat, and pilgrimage are practices in Islam that must be carried out with a healthy or strong physique, let alone war in the way of Allah and other forms of struggle. Therefore, physical health must receive the attention of a Muslim, and prevention from disease is far more important than medicine. Even so, we still consider illness as something normal when it happens occasionally, and don't let a Muslim get sick. Because physical strength is also an important thing, the Prophet Muhammad said which means: 'A strong mu'min I love more than a weak mu'min' (Narrated by Muslim).

Mutsaqaful Fikri Intellect in thinking (mutsaqqoful fikri) is an important aspect of the Muslim personality. Therefore, one of the characteristics of the Prophet is fatonah (intelligent) and the Qur'an reveals many verses that stimulate people to think, in the word of Allah SWT: "They ask you about, khamar and gambling. Say: 'in both of them there are major sins and several benefits for humans, but the sins of both are greater than the benefits. And they ask you what they support. Say: 'That is more than necessary.' Thus Allah explains His verses to you so that you think (QS 2: 219).

Mujahadatun Linafsihi Fighting against lust (mujahadatun linafsihi) is a personality that must exist in a Muslim because every human being tends to good and bad. Carrying out the inclination for the good and the avoiding of the bad demands a lot of sincerity and that sincerity will be present whenever one is struggling against lust. Therefore, the lust that exists in every human being must be endeavored to obey the teachings of Islam, Rasulullah Saw said which means: Not believing in someone from you so that he makes his desires follow what I carry (Islamic teachings) (HR. Hakim).

Harithun 'ala Waqtihi Being good at keeping time (harishun ala waqtihi) is an important factor for humans. This is because time itself received such great attention from Allah and His Messenger. Allah Swt swears a lot in the Qur'an by mentioning the names of times such as wal fajri, wad dhuha, wal asri, wallaili, and so on. Allah Most High gives time to humans in the same amount each, namely 24 hours a day and night. From that 24 hour period, there are humans who are lucky and not a few people who lose. Hence a slogan which states: 'It is better to lose hours than lose time'. Time is fleeting and will never come back. Therefore every Muslim is highly demanded to manage his time properly, so that time can pass with effective use, nothing is in vain. So among the things mentioned by the Prophet SAW were: "take advantage of the momentum of the five cases before the five cases come, namely life 
before death, health before illness, youth before old age, free before being busy and rich before being poor.

Munazhzhamun fi Syu'unihi Organized in a matter of affairs (munzhzhamun fi syuunihi) including the personality of a Muslim which is emphasized by both the Koran and the Sunnah. Therefore, in Islamic law, both issues related to ubudiyah and muamalah must be resolved and implemented properly. When an affair is handled collectively, it is imperative that we cooperate well so that Allah will be in love with him.

Qodirun 'alal Kasbi Having the ability to do business alone or also known as being independent (qodirun alal kasbi) is another characteristic that a Muslim must-have. This is something that is indispensable. Defending the truth and struggling to enforce it can only be done when a person has independence, especially from an economic perspective.

Naafi'un Lighoirihi Beneficial to others (nafi'un lighoirihi) is a requirement for every Muslim. The benefits in question are of course good benefits so that wherever he is, people around him feel his existence because it is of great benefit. This means that every Muslim must always think, prepare himself, and make the best of efforts to be useful in certain things so that a Muslim cannot take a good role in his society. HR. Bukhari Muslim: "Khoirunnas Anfa 'uhum linnas", which means: the best human being is what is beneficial to other humans.

The description of a believer with all the characteristics contained in the Al-Qur'an is a picture of a complete human being (insan kamil) in this life, within the limits that humans can reach. Allah wants us to be able to strive to make it happen in ourselves, Rasulullah saw had fostered the first generation of believers on the basis of these characteristics. He succeeded in completely changing their personalities of the ignorant people and shaping them as true believers who were able to change the face of history with their personal strength and moral dignity. [37] In short, the personality of a believer can be an example for others.

\section{Conclusion}

Personality or character, characteristic or character of a person that exists and is continuously maintained, however, personality can change according to the influencing factors. In Islam the Muslim personality is synonymous with Islamic morals, it is a harmonious blend of the system of the heart, reason, and lust that causes behavior and is a characteristic of Muslims. Because of that, the characteristic of a Muslim personality is that he always keeps his heart to obey Allah so that he always gets his light and keeps away from all his prohibitions which are human excrement.

The structure of the Muslim personality includes three substances, namely body or body, spirit or spirituality, and nafsani or soul, the soul itself consists of the heart, reason, and lust. While lust consists of lust, anger, and muthmainah. All of these are the structures of Islamic personality, which if the system works well all will form the personality of a kamil or a complete human being who is calm, always does good, tawakal, and avoids despicable traits.

And the characteristics of Muslim personality are 10: Aqidah that is clean, true worship, strong morals, physical strength, intellect in thinking, fighting against lust, good at keeping time, organized in matters of affairs, having the ability to work on their own or what is also called independently and Beneficial for others. But in fact, there are often psychiatric disorders that can reduce the degree of personality or mental health. To heal it one has to go through continuous mental training such as patience, repentance, tawakal, pleasure, and so on. 


\section{References}

Allison, G. T., \& Zelikow, P. (1971). Essence of decision: Explaining the Cuban missile crisis (Vol. 327, No. 729.1). Boston: Little, Brown.

Carr, A., \& Pihlanto, P. (1998). From homo mechanicus to the holistic individual: a new phoenix for the field of organisation behaviour?. Current topics in management, 3 , 69-91.

Darlington, K. (2000). The essence of expert systems.

El-Shamy, H. M. (1976). Behaviorism and the Text.

Fleeson, W. (2001). Toward a structure-and process-integrated view of personality: Traits as density distributions of states. Journal of personality and social psychology, 80(6), 1011.

Funk, R., \& Shaw, M. (1982). Erich Fromm: The courage to be human (p. 7). New York: Continuum.

Larsen, R. J. (1989). A process approach to personality psychology: Utilizing time as a facet of data. In Personality psychology (pp. 177-193). Springer, New York, NY.

Lorenz, E. N. (1995). The essence of chaos. University of Washington press.

Molden, D. C., \& Dweck, C. S. (2006). Finding" meaning" in psychology: a lay theories approach to self-regulation, social perception, and social development. American Psychologist, 61(3), 192. 